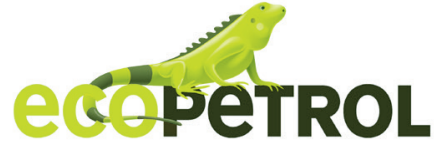

ctyf@ecopetrol.com.co

\title{
NEW BORON-NITROGEN CONTAINING MODIFIED MULTIFUNCTIONAL ALKYLPHENOLATE ADDITIVES
TO MOTOR OILS
}

NUEVOS ADITIVOS MULTIFUNCIONALES PARA ACEITE DE MOTOR BASADOS EN ALQUILOFENATO MODIFICADOS QUE CONTENIEN BORO Y NITRÓGENO

Mammadova, Afayat-Khalila*; Farzaliyev, Vagif-Mecid ${ }^{a}$; Kazimzadeh, Ali-Kazim ${ }^{a}$

\begin{abstract}
By carrying out condensation reactions for alkylphenols and methylene-bis-alkylphenols with amines, alkanolamines and formaldehyde, working with boric acid and the neutralization of the obtained product with calcium hydroxide, new boron-nitrogencontaining alkylphenolate, additives have been synthesized (AKI-114B, AKI-212B, AKI-115B, AKI-210B, AKI-214B, AKI-219B).

The structure of the obtained - boron esters (derivatives of phenolate) has been studied through the use of the IR spectroscopy method. Simultaneously with studying the functional properties of the synthesized additives in motor oil, it has been established that their detergent, water, corrosion, oxidation and wear resistance properties greatly overbalance the same properties of their single nitrogen-containing and industrial analogues. Through thermoanalytic research conducted on OD-102T typed derivatograph, the high stability (through to $360^{\circ} \mathrm{C}$ ) of additives containing boron-nitrogen has been determined.

On the basis of new boron, nitrogen-containing modifications AKI-210B and AKI-115B different motor oil compositions such as M-8B, M-10G2 and etc. have been prepared and tested. The creation of high-synergy efficiency upon interaction of synthesized additives with other ones (sulfonates, dithiophosphates) has been observed, particularly in the improvement of tribological properties, and the increase in the oxidation induction period.
\end{abstract}

\section{RESUMEN}

Nuevos aditivos para aceite de motor basados en alquilofenatos modificados que contienen Boro y Nitrógeno (AKI-114B, AKI212B, AKI-115B, AKI-210B, AKI-214B, AKI-219B), se sintetizan mediante reacciones de condensación de alquilofenoles y metilbis, alquilofenoles con aminas, alcanolaminas y formaldehído. Los productos de reacción se neutralizan con Hidróxido de Cálcio.

La estructura de los ésteres de Boro (derivados del fenolato) ha sido analizada a través del uso del método de espectroscopía IR. El estudio de las propiedades funcionales de los aditivos sintetizados para el aceite de motor, ha establecido que sus propiedades detergentes de agua, de corrosión, de oxidación y de resistencia al desgaste superan en gran medida en las mismas propiedades a los aditivos que contienen nitrógeno y aditivos industriales análogos. La investigación termo analítica realizada en un derivatógrafo OD-102T permitió determinar que los aditivos conteniendo Boro-Nitrógeno tienen una alta estabilidad (hasta $360^{\circ} \mathrm{C}$ ).

Sobre la base de los nuevos aditivos Boro- Nitrógeno se prepararon las modificaciones AKI-210B y AKI-115B y diferentes composiciones de aceite de motor tales como M-8B y M-10G las cuales fueron igualmente evaluadas. Se ha observado la creación de una alta eficiencia y sinergia tras la interacción de aditivos sintetizados con otros (sulfonatos, ditiofosfatos), particularmente en la mejora de las propiedades tribológicas y el aumento en el período de inducción de la oxidación.
Alkylphenolate | Amine | Alkanolamine | Boric Acid | Additives | Motor oil.

Alquilofenato | Amina | Alcanolamina | Ácido Bórico |

Aditivos | Aceite de motor.
${ }^{a}$ Academician A.M.Guliyev Institute of Chemistry of Additives of Azerbaijan National Academy of Sciences, Beyukshor Highway, Block 2062, Baku AZ 1029,

Republic of Azerbaijan. *email: aki05@mail.ru 


\section{INTRODUCTION}

The coordination bond that boron atoms form with nitrogen atoms, especially cyclic ethers formed by alkanolamines, increase the water and temperature resistance of the boron containing organic compounds.

Boron atoms adsorbed on the surface of the metal form an isolated layer with it, while also overcoming the catalytic effects of metal in the oxidation process. With an increase in temperature $\mathrm{B} 2 \mathrm{O} 3, \mathrm{Fe}_{3} \mathrm{~B}_{2}$ and BN layers are formed. It improved the tribiological properties of the additives and improved its oxidation and corrosion properties.
Existence of $\mathrm{O}=\mathrm{B}-\mathrm{O}-\mathrm{B}=\mathrm{O} . . ., \mathrm{HN},>\mathrm{N} \rightarrow \mathrm{B}-\mathrm{OH}$ fragments in nitrogencontaining com $\neg$ pounds, for example: in borated succinimides and amines, increasing the temperature resistance and at the same time detergent-dispersive properties. In order to increase the dissolving of boron compounds in oil and effectiveness of a complex of boron atoms with nitrogen-containing organic compounds, boron ethers are used at the same time. [1]-[6].

Due to this,it is possible that their exploitation features would be increased when embedding the boron atom in the nitrogen molecule containing alkylphenolate additives.

\section{EXPERIMENTAL DEVELOPMENT}

Obtaining the synthesized alkylphenolate typed boron-containing additives was carried out in the following steps:

1. Condensation of alkylphenol or methylene-bis-alkylphenol with formaldehyde or para-form and amine compounds (ammonia, octadecylamines, mono-and diethanolamines, alkenylsuccinimids). Synthesized on Mannich base to be controlled for ester variant by refraction ratio of mixture.

2. Processing of the condensation product with boric acid; (6.68.0\% due to alkylphenol upon provided additives)

3. Neutralization of the obtained product with calcium hydroxide. (18-20\% due to alkylphenol (weight part) upon provided additives).Diluent oil is diluent I-12A. Each additive is released from the water, getting dried, centrifuged for cleaning from impurities and thinners (benzole, heptane). Within the framework of the aforementioned steps, we have obtained boron-nitrogen-containing alkylphenolate additives (not known to literature) with the formulas indicated below [7]-[9].

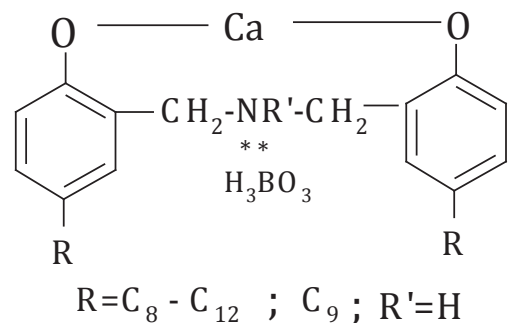

\section{AKI-114B}

Calcium salt from the product of condensation of alkylphenolate with formaldehyde and ammonia and processing with boric acid;<smiles>[R]=C=C=[R]</smiles>

\section{AKI-210B}

Calcium salt from the product of condensation of methylene-bisalkylphenol with formaldehyde and diethanolamine and processing with boric acid;

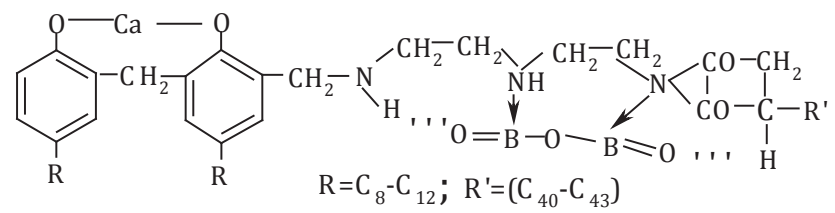

AKI-214B

Calcium salt from the product of condensation of methylene-bisalkylphenol with alkenyl- succinimide and paraform and processing with boric acid.

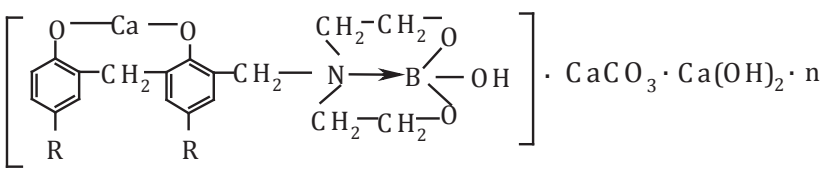

AKI-219B

Carbonated calcium salt from the product of condensation of methylene-bis-alkylphenol with diethanolamine and formaldehyde and processing with boric acid.

This additive is a carbonated variant of $\mathrm{AKI}-210 \mathrm{~B}$ additive. The feed rate of $\mathrm{CO}_{2}$ gas during carbonatation is $15-16 \mathrm{ml} / \mathrm{min}$ at the temperature $70-80^{\circ} \mathrm{C}$. 
The characterization of physicochemical and functional properties of boron nitrogen containing additives is provided in Table 1. IR-spectrums were recorded using a Fourier-Nicolet iS-10 IR Spectrometer, made in the United States of America.

Thermooxidation properties of synthesized alkylphenolate additives have been studied by derivatographic analysis at ОД-102Т Paulik (Hungary) typed derivatograph with dynamic working mode at air conditions and a temperature of $10^{\circ} \mathrm{C}$. As a sample, $0.1 \mathrm{~g}$ of standard aluminum oxide is used.

\section{RESULTS AND ANALYSIS}

It is clear from Table 1 that boron-nitrogen-containing additives are significantly better $(0.03-0.08 \%$ against $1.0-1.2 \%, 0.38-0.40$ $\mathrm{mm}$ against $0.5-0.55 \mathrm{~mm}$ ) than their single nitrogen-containing analogues regarding antioxidation and antiwear properties, as well as regarding detergent-dispersive and anticorrosion properties. For example: a succinimide fragment containing AKI-214"B" additive has better detergent properties than its analogue without boron ( 0 point).

The multifunctionality of boron-nitrogencontaining alkylphenolates makes it possible to create high-quality motor oils based on them. Creation of ether groups in modifications obtained on the basis of alkanolamine was determined by IR spectrum analysis of the products received from first condensation through to last neutralization.

Absence of a peak belonging to $\mathrm{NH}$-group in the IR spectrum of aminomethylation product of alkhanolamines with methylen- bis-alkylphenol and presence of $1049.54 \mathrm{~cm}^{-1}$ zone characterizing $-\mathrm{C}-\mathrm{O}-$ bond in alcohols, and diffuse line overlapping by $\mathrm{OH}$ groups of phenol at 3362,29 $\mathrm{cm}^{-1}$ confirms the structure of the aminomethylized product (Figure 1). In the IR spectrum of the intermediate product obtained after condensation of aminomethylized product with $\mathrm{B}(\mathrm{OH})_{3}$ we observe the $-\mathrm{C}-\mathrm{OH}$ - group, the absence of $1049.54 \mathrm{~cm}^{-1}$ zone, and instead of it formation of $1160.40 \mathrm{~cm}^{-1}$ zone, which can be said belongs to the $-\mathrm{C}-\mathrm{O}-$ bond of ether groups (Figure 2 ).

Appearance (for sliding) of simple ether groups at $1131.56 \mathrm{~cm}^{-1}$ or $1129.46 \mathrm{~cm}^{-1}$ in the final product - phenolates proves the creation and maintenance of ether-covalent $>\mathrm{B}-\mathrm{O}-\mathrm{C}$-group bonds until the end.

Coordination bonds can be easily created at low temperatures $\left(80-85^{\circ} \mathrm{C}\right)$. Virtual absence of observed zone in phenolic $\mathrm{OH}$ after condensation of phenolate with boric acid in the IR spectrum of phenolates confirms that the phenolate was obtained (Figures 3 and 4).

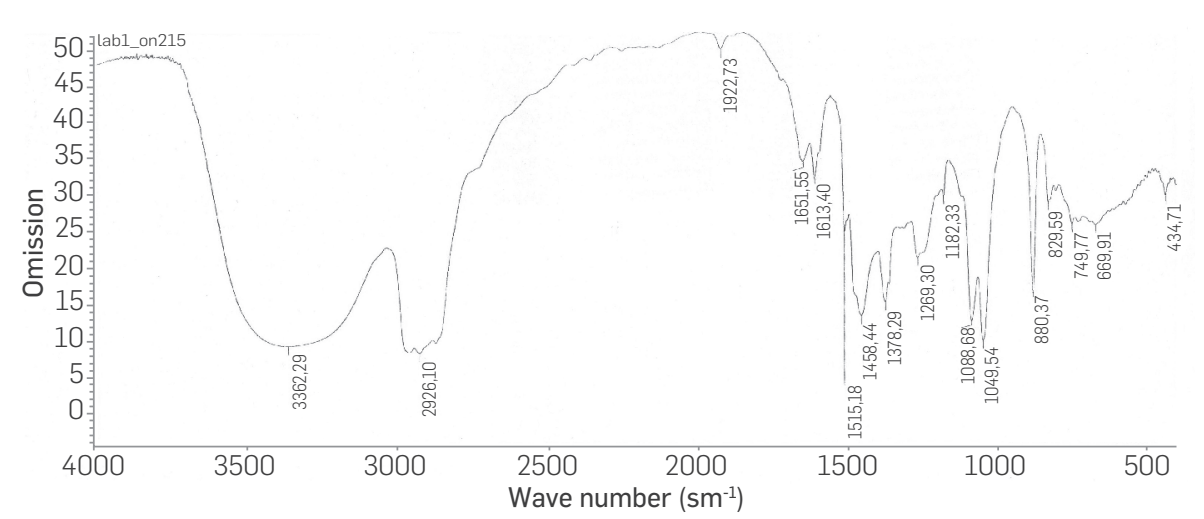

Figure 1. IR spectrum of aminomethylation product of alkylphenol with diethanolamine

Table 1. Physicochemical and functional properties of boron-nitrogen-containing alkylphenolate additives.

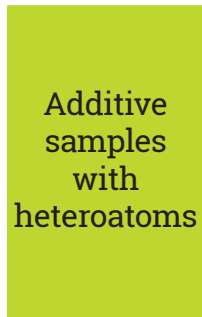

AKI-114 (N)

AKI-114 "B"(N)

AKI-115 (N)

AKI-115"B"(N)

AKI-212"B"(N)

AKI-210"B" (N)

AKI-214"B" (N)

AKI-219(B, N)

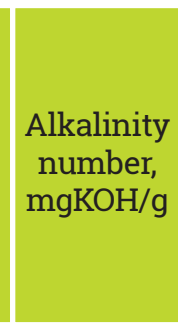

$95-100.8$

106.4

$110-115$

125.7-130

76.4

120-128

78.0-82.0

150-160

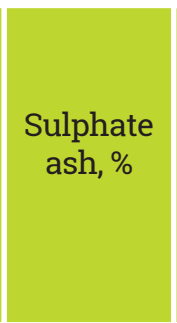

$9.7-9.8$

9.95

10.5

11.01

7.4

$10.5-11.5$

6.5-7.0

17.5

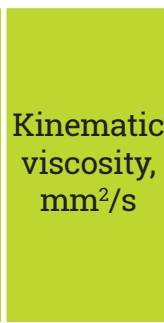

$73.5-76.9$

68.5

75-90

67.1-89.1

56.0

$75.0-85.0$

79.0-86.0

89.0

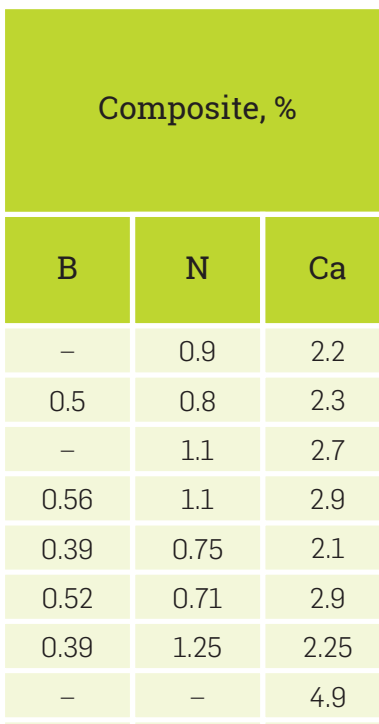




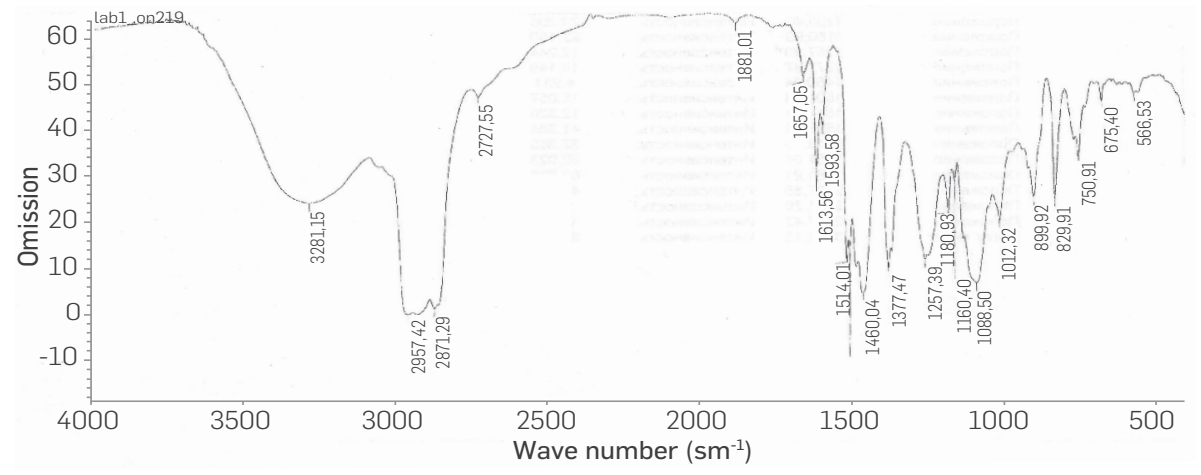

Figure 2. IR spectrum of the product of aminomethylation of alkylphenol with diethanolamine and condensation with boric acid

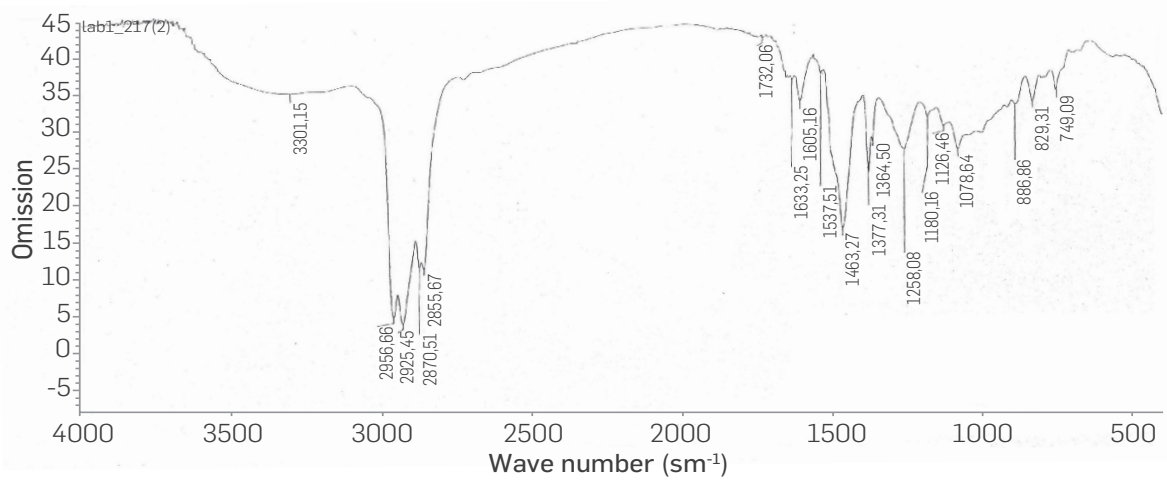

Figure 3. IR spectrum of calcium salt from the product of aminomethylation of alkylphenol with diethanolamine and condensation with boric acid

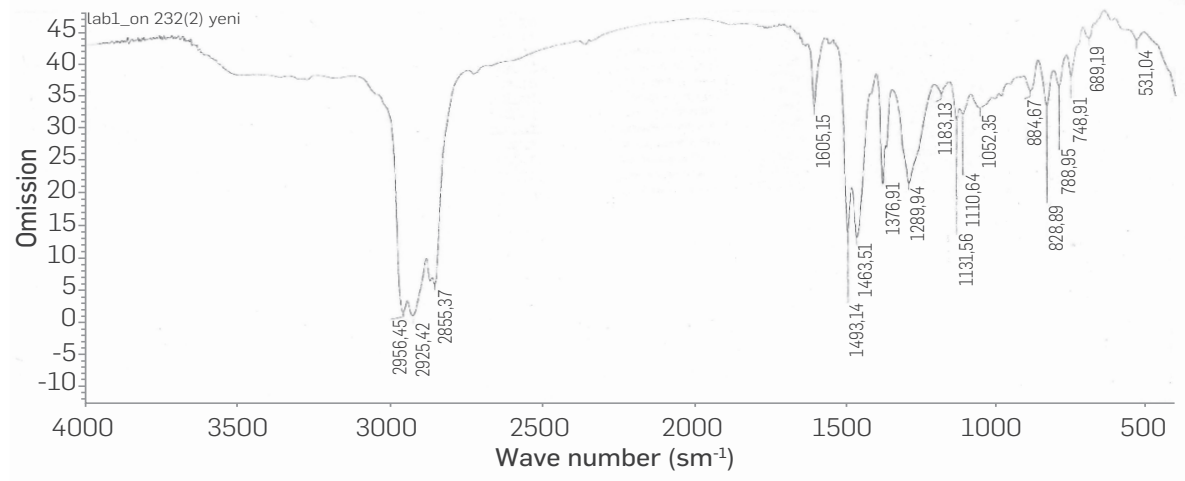

Figure 4. IR spectrum of calcium salt from the condensation product of alkylphenol with monoethanolamine and boric acid examples are defined by exothermic effects and this is shown in differential-thermal analysis curves (DTA).

The thermooxidation stability of AKI-114"B" is $320^{\circ} \mathrm{C}$ and difference between it and AKI114 is just $10^{\circ} \mathrm{C}$. At the same time, as can be seen from the DTA of AKI-114"B", the exo-effect is considerably less than the same indicator for the additive without boron. In this part of the curve, borders have a spread shape. But in the condensation products of additives (CP) the beginning of the second stage of destruction for CP of AKI-114 and AKI-114"B" additives is 2850C and $310^{\circ} \mathrm{C}$, respectively. The maximum level for thermodestruction without boron is $610^{\circ} \mathrm{C}$ and with boron it is $700^{\circ} \mathrm{C}$ (Figure 5).

The first stage for thermodestruction of the condensation products of AKI-115 and $\mathrm{AKI}-115 \mathrm{~B}$ additives is $300^{\circ} \mathrm{C}$ and $320^{\circ} \mathrm{C}$ respectively, but in the additives it is $345^{\circ} \mathrm{C}$ and $360^{\circ} \mathrm{C}$, respectively. But half-life period $\mathrm{T}_{50 \%}$ makes $360^{\circ} \mathrm{C}$ for the AKI-115 additive, and $400^{\circ} \mathrm{C}$ for AKI-115"B". The thermooxidation efficiency (exo-effect) of AKI-115B in comparison with analogues is observed at temperatures of more than 200C (Table 2, Figure 6).

As can be also seen from Table 2, the difference between thermostability indicators of $\mathrm{AKI}-114 \mathrm{~B}$ and $\mathrm{AKI}-115 \mathrm{~B}$ additives is $40^{\circ} \mathrm{C}\left(320-360^{\circ} \mathrm{C}\right)$. It shows moving thermo-chemical transformations (thermooxidation stability) of solvent oil contained in the additives, which usually takes place at $280-290^{\circ} \mathrm{C}$ to hightemperature zones [10].

At the same time according to Table 2 , the half-life period for such industrial samples as ACK and MACK, which are part of the carboxylate group containing additives, makes $340-345^{\circ} \mathrm{C}$. The thermooxidation stability of nitrogen-containing carboxylate can be compared with boron-nitrogencontaining ones. Both of them are a little higher than sulfur-containing ones.

\section{COMPARISON OF THERMOOXIDATION PROPERTIES OF BORON-NITROGEN-CONTAINING ALKYLPHENOLATE ADDITIVES WITH INDUSTRIAL AND SYNTHESIZED ANALOGUES}

The thermostability of additives is determined by the ending temperature of the first stage and beginning temperature of the second stage of destruction, thermogravimetric (TQ) curves by weight loss $\left(T_{10 \%}, T_{20 \%}, T_{50 \%}, T_{70 \%}\right)$, and the thermooxidation degrees of
AKI-114 - Calcium salt of condensation product of alkylphenol with ammonia and formaldehyde [11];

AKI-115 - Calcium salt of condensation product of alkylphenol with monoethanolamine and formaldehyde [7]

VNIINP-714-Carbonated calcium salt of thio-bis-alkylphenol [12];

OLOA-218A-Carbonated calcium salt of thio-bis-alkylphenol [13]; ASK-Calcium alkylsalicylate; 
Table 2. Comparative thermooxidation stability of alkylphenol additives

\begin{tabular}{|c|c|c|c|c|c|c|}
\hline \multirow{2}{*}{$\begin{array}{l}\text { Additives } \\
\text { Cont. } \\
\text { heteroatomsan } \\
\text { func. } \\
\text { groups. }\end{array}$} & \multirow[t]{2}{*}{$\mathrm{T}_{10 \%},{ }^{\circ} \mathrm{C}$} & \multirow[t]{2}{*}{$\mathrm{T}_{20 \%},{ }^{\circ} \mathrm{C}$} & \multirow[t]{2}{*}{$\mathrm{T}_{50 \%},{ }^{\circ} \mathrm{C}$} & \multirow[t]{2}{*}{$\mathrm{T}_{70 \%},{ }^{\circ} \mathrm{C}$} & \multicolumn{2}{|c|}{$\begin{array}{l}\text { The end of the } 1^{\text {st }} \text { stage } \\
\text { of thermodestruction and } \\
\text { the beginning of the } \\
2^{\text {nd }} \text { stage }\end{array}$} \\
\hline & & & & & $\begin{array}{l}\text { temperature, } \\
{ }^{\circ} \mathrm{C}\end{array}$ & $\begin{array}{c}\text { weight loss, } \\
\%\end{array}$ \\
\hline AKI-114 (N) & 225 & 285 & 370 & 495 & 310 & 42 \\
\hline AKI-114"B" (N) & 235 & 275 & 390 & 495 & 320 & 34 \\
\hline AKI-115(N) & 250 & 285 & 360 & 465 & 345 & 47 \\
\hline AKI-115“B” (N) & 270 & 310 & 400 & 475 & 360 & 40 \\
\hline VNIINP -714 (S) & 230 & 270 & 355 & 440 & 335 & 44 \\
\hline OLOA-218A (S) & 250 & 295 & 370 & 460 & 320 & 40 \\
\hline ACK $(\mathrm{COOH})$ & 265 & 295 & 345 & 385 & 330 & 45 \\
\hline MACK $(\mathrm{COOH})$ & 265 & 280 & 340 & 400 & 340 & 50 \\
\hline
\end{tabular}

MASK-High-alkalinity alkylsalicylate [14].

It is clear from the table that the modified alkylphenolate additive AKI-115"B" has the highest thermostability indicators $\left(360^{\circ} \mathrm{C}\right)$.

It has been established that thermostability of:

Boron-containing additives is higher $\left(10-20^{\circ} \mathrm{C}\right)$ than analogues without boron;

- Carbonated high alkalinity additives is much higher $\left(10-15^{\circ} \mathrm{C}\right)$ than average alkalinity ones;

- Additives obtained on the basis of alkanolamines is higher $\left(30-40^{\circ} \mathrm{C}\right)$ than additives containing primary amine.

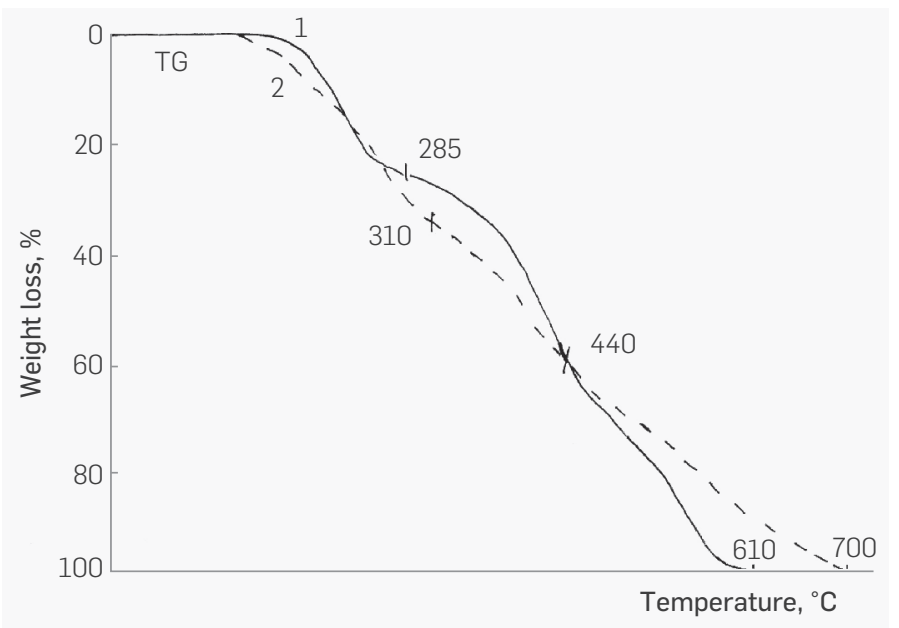

Figure 5. Thermogravimetric curves for the condensation products of AKI-114 (1) and AKI-114B (2) additives 1.AKI-115; 2. AKİ-115B, 3. AKI-114B

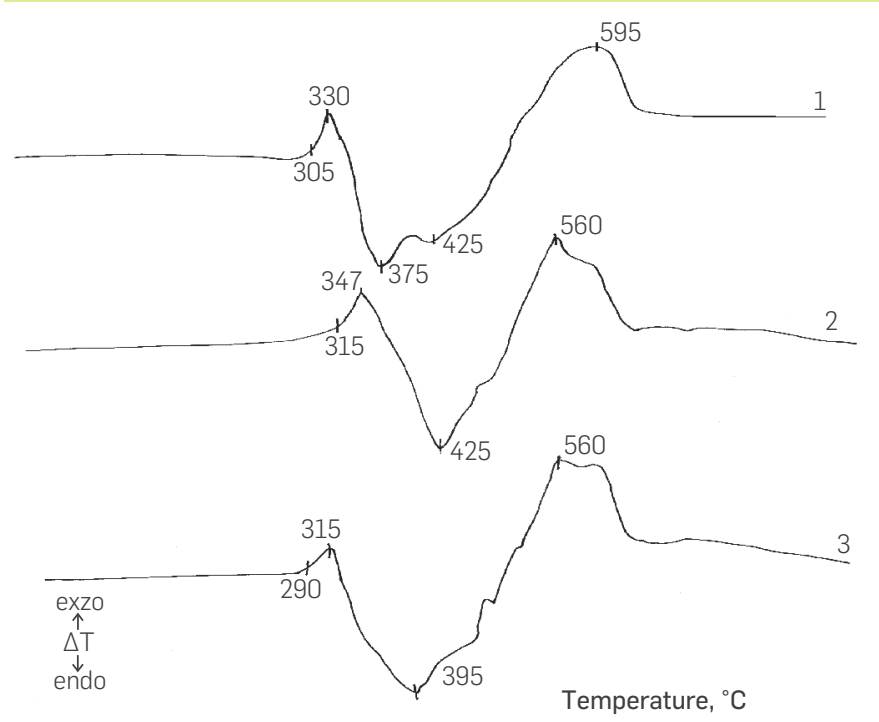

Figure 6. DTA additive curves 1. AKI-115; 2. AKI-115B, 3. AKI-114B
Through use of the above-mentioned heteroatom-containing additives, several motor oil compositions for gasoline and diesel engines have been developed. For example, $M-10 G_{2}$ oil is an industrial diesel, especially heavy-loaded auto-tractor diesel oil produced to GOST 8581. This $M-10 G_{2}$ oil has been prepared by use of VNIINP-360 additive with insignificant multifunctionalty tribological properties and average alkalinity.

Through use of the boron-nitrogen-containing AKI-115B, an additive composition meeting the requirements of the oil has been created.

On the basis of the oil and a small portion of AKI-210B and AKI115B additive and other components, oil compositions have been developed and tested $\mathrm{M}-10 \mathrm{G}_{2} \mathrm{k}, \mathrm{M}-10 \mathrm{~V}_{2}$ [15], [16].

In Tables 3 and 4 there are ASTM numbers and GOST methods according to which physicochemical and functional properties of oils are determined. Both compositions of oils $M-8 B$ and $M-10 G_{2}$. meet modern requirements. [17]-[19].

So, it has been shown that the multi-functionality and high efficiency of boron nitrogen-containing alkylphenolate additives make possible their use as part of motor oil for gasoline and diesel engines that meet modern requirements.

\section{CONCLUSIONS}

For the first time, on the basis of the condensation of alkylphenoles with formaldehyde, amines, alkanol amines and boric acid step by step, boron-nitrogen-containing alkylphenolate additives have been synthesized, with several advantages having been determined for boron-containing additives (AKI-114B, AKI-115B, AKI-210B, AKi212B, AKI-214B, AKI-219B) in comparison with their analogues without boron:

detergent properties ( 0 points against 0.5-1.0 points); 
Table 3. Physicochemical and functional properties of M-8B oil composition with AKI-210B additive

\begin{tabular}{|c|c|c|c|}
\hline Indicators & $\begin{array}{l}\text { M-8B oil GOST } \\
\text { 10541-78 norm }\end{array}$ & $\begin{array}{l}\text { Experimental } \\
\text { motor oil with } \\
\text { AKİ-210"B" } \\
\text { additive }\end{array}$ & $\begin{array}{l}\text { The oil firm } \\
\text { Shell Rimula } \\
\text { C20W-20 }\end{array}$ \\
\hline Kinematic viscosity, $100^{\circ} \mathrm{C}, \mathrm{mm}^{2} / \mathrm{s}$ & $8 \pm 0.5$ & 8.2 & 8.8 \\
\hline Viscosity index, not less than & 93 & 94 & 102 \\
\hline Base number, $\mathrm{mgKOH} / \mathrm{g}$ not less than & 4.2 & 5.1 & 4.5 \\
\hline Sulfate ash, \%, not more than & 0.95 & 0.88 & 0.78 \\
\hline Weight of mechanical mixture, $\%$, not more than & 0.015 & 0.010 & - \\
\hline Flash Point determined at the open pot ${ }^{\circ} \mathrm{C}$, not less than & 207 & 220 & 236 \\
\hline Freezing temperature ${ }^{\circ} \mathrm{C}$, not more than & Minus 25 & Minus 25 & Minus 21 \\
\hline Stability on induction period of precipitation formation (SFIP), 30 hours, \% & - & 0.1 & - \\
\hline Corrosion (on lead plates) $\mathrm{g} / \mathrm{m}^{2}$, not more than & 10 & stable (0.3-1.0) & - \\
\hline Detergent properties (due to PZV) point, nor more than & 0.5 & 0.5 & 0.5 \\
\hline
\end{tabular}

Table 4. Physicochemical and functional properties of $\mathrm{M}-10 \mathrm{G}_{2}$ oil composition with AKI-115B additive

\begin{tabular}{|c|c|c|c|c|c|}
\hline \multirow{2}{*}{ Indicators } & \multirow{2}{*}{$\begin{array}{c}\text { M-10G } \\
\text { oil GOST } \\
8581-78 \\
\text { norm }\end{array}$} & \multirow{2}{*}{$\begin{array}{c}\text { M-10G } \\
\text { oil } \\
\text { AKİ-115B } \\
\text { additive }\end{array}$} & \multirow{2}{*}{$\begin{array}{c}\text { The oil firm } \\
\text { Shell Rotella } \\
\text { TX-30 }\end{array}$} & \multicolumn{2}{|c|}{ Test method } \\
\hline & & & & GOST & ASTM \\
\hline Kinematic viscosity, $100^{\circ} \mathrm{C}, \mathrm{mm}^{2} / \mathrm{s}$ & $11 \pm 0.5$ & 10.9 & 10.8 & 33 & D 445 \\
\hline Viscosity index, not less than & 85 & 94 & 102 & 25371 & D 2270 \\
\hline Base number, $\mathrm{mgKOH} / \mathrm{g}$ not less than & 6.0 & 8.5 & 9.4 & 11362 & D 4739 \\
\hline Sulfate ash, $\%$, not more than & 1.65 & 1.1 & 1.3 & 12417 & D 874 \\
\hline Flash point determined at the open pot ${ }^{\circ} \mathrm{C}$, not less than & 205 & 215 & 202 & 4333 & D 92 \\
\hline Freezing temperature ${ }^{\circ} \mathrm{C}$, not more than & Minus 15 & Minus16 & Minus 18 & 20287 & D 97 \\
\hline Weight of mechanical mixture, $\%$, not more than & 0.015 & 0.008 & 0.010 & 6370 & - \\
\hline Density, $20^{\circ} \mathrm{C}, \mathrm{kg} / \mathrm{m}^{3}$, not more than & 905 & 905 & 896 & 3900 & D 4052 \\
\hline $\begin{array}{l}\text { Stability on induction period of precipitation } \\
\text { formation (SFIP), } 40 \text { hours, \% }\end{array}$ & $\begin{array}{l}40 \\
(0.5)\end{array}$ & $\begin{array}{c}40 \\
(0.08)\end{array}$ & $\begin{array}{l}40 \\
-\end{array}$ & 11063 & - \\
\hline Corrosion (on lead plates) $\mathrm{g} / \mathrm{m}^{2}$, not more than & 20 & Stable & Stable & 20502 & - \\
\hline Detergent properties (due to PZV) point, not more than & 1.0 & 0.5 & 0.5 & 5726 & D 892 \\
\hline
\end{tabular}

antiwater stability: alkalinity reduction (13-15\% against 1820\%);

along with slightly improved corrosion, higher oxidation stability (the amount of precipitation is reduced from $1.2 \%$ to 0.03-0.05\%);

prevailing thermooxidation properties: according to results of the thermogravimetric analysis, the beginning of the second phase of thermodestruction makes 320-3600C;

AKI-115"B"additive obtained from alkanolamine has higher thermal oxidation stability (3600C) than additives obtained from primary amines; the antiwear properties of boron-containing additives is higher than the same properties for nitrogen-containing analogues (wear scar diameter $0.40 \mathrm{~mm}$ against 0,55 mm).

Taking into account everything mentioned above, it is possible to create modern motor oil compositions through the application of additives containing boron-nitrogen. 


\section{REFERENCES}

[1] Wolfgang Knoblauch, Burghausen; Konrad von Werner, Burgkirchen, US. Patent. 4204972. Hydraulic fluids comprising nitrogen containing boric acid esters. / Fed. Rep of Germany, 1980

[2] Thomas V. Liston, San Rafael, (Calif), US Patent. $4455243 \mathrm{~J}$. Succinimide complexes of borated fatty acid esters of glycerol and lubricating oil compositions containing same. / Chev. Res. Comp., 1984

[3] Carl F. Stachew, Wickliffe, James R. Shankline Concord both of Ohio, US Patent. 6010986. Alcohol borate esters to improve bearing corrosion in engine oils. / The Lubriz. Corp., 2000

[4] Vernon R. Small., Jr. Rodeo, Thomas V. Liston, San Rafael, Anatoli Onopchenko Concord, US Patent. 5141660. Monoalkylamine complexes of borated alkyl catechols and lubricating oil compositions containing the same. Calif., 1992

[5] Belyaeva O.V.. Shabanova E.V., Use of boroncontaining compounds as additives to lubricating oils. Neftyaniye i sinteticheskiye smazochniye materiali. [Oil and synthetic lubricating materials], No.55, 47-56. (in Russian), 1988

[6] Borisenko L.V., Whipper A.B., Lashkhi V.L., Boroncontaining compounds as antifriction and anti-wear additives to lubricating oils. Khimiya i tekhnologiya topliv masel [Chemistry and technology of fuels and oils], No.3 41-42. (in Russian), 1984

[7] Mammadova A.Kh., Boron-nitrogen-containing alkylphenolate additives to mineral oils. Azerbaijanskoye neftyanoye khozyaystvo [Azerbaijan Oil Industry], No.3, 62-65. (in Russian), 2007

[8] Mammadova A.Kh., Farzaliyev V.M., Kazimzadeh A.K., Nagiyeva E.A. et.al. / New boron-nitrogencontaining modified alkylphenolate additive to motor oils. [Azerbaijan oil Industry], No. 3, 43-45 (in Azerbaijani), 2014

[9] Mammadova A.Kh, et.al. Az. Patent No. I 20160016 Motor yaglarina chokfunksiyali ashqarlarin alinma usulu [The method of preparation of multifunctional additive to motor oils]. Azerbaijan], 2016

[10] Akchurina T.Kh., Mammadova A.Kh., Nagiyeva E.A., Hamidova Sh.Ya., Thermoanalytical studies of polyfunctional boron-containing additives of alkylphenolate type. Khimicheskiy jurnal Gruzii [Chemical Journal of Georgia], vol.8, no 4, pp.346-348. (in Russian) 2008

[11] Zeynalova G.A., Kazimzadeh A.K., Nagiyeva E.A. Mammadova A.Kh., SSSR In $\neg$ ventor's Certificate No 1774647., Lubricating oil. Azerbaijan, 1992.

[12] Seleznyova N.E., Levin A.Ya., Monin S.V., Detergentdispersant additives to mo-tor oils. Khimiya i tekhnologiya topliv i masel [Chemistry and technology of fuels and oils], No 6, 39-43. (in Russian), 1999

[13] Whipper A.B., Vilenkin A.V., Gaysner D.A., Zarubejniye masla i prisadki. [Foreign oils and additives]. Moscow: Khim, 150-158 (in Russian), 1981.

[14] Additives to Motor and Transmission Mineral Oils] Prisadki k motornim i transmissionnim mineralnim maslam. Masma VNIIPK Neftechem NGO Directory. Kiev (in Russian), 1985.

[15] Cavadova H. A., Ramazanova Y.B., Mammadova A.Kh. et.al. (2016) Az. Patent. 2016 0120. Engine oil for pneumatic auto-tractor and stationary diesels.
[16] Cavadova H. A. Ramazanova Y.B. Mammadova A.Kh et.al. Az. Patent. 2017 0014. Engine oil for enhanced auto-tractor diesels, 2017

[17] Savchenko A.I., Directory, over lubricating oils firm Shell translate English. Baku, 1983

[18] Technical Data Sheet (Extra Performance Monograde) of the Shell Rimula R3 20W-20 (CF) [Online] Avalilable: http://arizonamotors.ro/userfiles/ product files shared/TDS\%20SHELL\%20RIMULA\%20 R3\%2020W20\%20ARIZONAmotors.ro.pdf

[19] Schkolnikov V.M., Directory, lubricating materials, Technical fuels Moscow Publishing centre «Techinform» International Academy Information., 1999 
INVESTIGADORES DEL INSTITUTO COLOMBIANO DE PETROLEO - ICP HAN DESARROLLADO BIOFILTROS CON ESPECIES VEGETALES, PARA EL PULIMENTO DE LA CALIDAD DEL AGUA INDUSTRIAL, CON EL FIN DE PROTEGER LOS ECOSISTEMAS ACUÁTICOS.

Researchers from the Colombian Petroleum Institute - ICP have developed biofilters using plant species for the polishing of industrial water quality, in order to protect aquatic ecosystems 